Jurnal Onoma: Pendidikan, Bahasa dan Sastra PBSI FKIP Universitas Cokroaminoto Palopo Volume 6 Nomor 2
ISSN 2443-3667 (print)

ISSN 2715-4564 (online)

\title{
Bahasa Figuratif dalam Tonis Masyarakat Dawan di Kabupaten Timor Tengah Selatan
}

\author{
${ }^{1}$ Metropoly Merlin J. Liubana; ${ }^{2}$ Ibrahim Nenohai \\ ${ }^{1}$ Program Studi Pendidikan Bahasa dan Sastra Indonesia, Fakultas Ilmu Pendidikan \\ Universitas Timor; ${ }^{2}$ SMA Negeri Santian \\ ${ }^{1}$ mmerlin2007@gmail.com,2nifukliko@gmail.com
}

\begin{abstract}
Abstrak
Penelitian ini bertujuan membahas gaya bahasa yang terkandung dalam tonis (tuturan lisan) masyarakat Dawan di Kabupaten Timor Tengah Selatan. Gaya bahasa yang dibahas berupa bahasa figuratif. Penelitian ini bersifat deskriptif kualitatif, dengan data emik berupa tuturan tonis pada masyarakat Dawan di kabupaten Timor Tengah Selatan. Pengumpulan data dilakukan dengan cara mengobservasi, merekam dan mencatat. Teknik menganalisis secara deskriptif, dengan langkah mentranskripsikan data lisan ke data tulis, menerjemahkan secara bebas, mengidentifikasi, menafsirkan, dan menguraikan secara detail, lalu menarik simpulan. Hasil penelitian menunjukan adanya gaya bahasa figuratif berjenis simile, dan personifikasi yang mendominasi tonis perpisahan tersebut. Bahasa figuratif perbandingan berupa simile terdapat pada data nomor; 9, 12, 13, 15, 18; bahasa figuratif berjenis personifikasi tertera pada data 6, 9, 10, 12, 13 .
\end{abstract}

Kata Kunci: bahasa figuratif, tonis.

\section{Pendahuluan}

Sastra adalah sebuah karya yang diproduksikan dari proses kreativitas imajinasi seseorang. Proses penciptaan sebuah karya sastra juga ditunjang dengan berbagai unsur yang membangunnya. Salah satu unsur pembangun karya sastra adalah gaya bahasa. Gaya bahasa merupakan style berbahasa dalam penyampaian ide baik yang berbentuk tulisan atau lisan kepada orang lain. Penggunaan gaya bahasa setiap penulis atau penutur berbeda-beda. Seperti yang dikemukakan Sukada dalam (Ratna, 2009:12) Gaya bahasa adalah bahasa itu sendiri; pilihannya berdasarkan struktur tertentu; penggunaannya wajar; memiliki ciri personal; lahir dari diri pribadi penutur/penulis secara jujur; disusun dengan sengaja agar menimbulkan efek tertentu; berisi tentang keindahan dan kebenaran. Seorang penulis atau penutur sastra baik sastra tulis maupun sastra lisan memiliki gaya bahasa yang berbeda.

Sastra lisan merupakan bentuk karya sastra yang dilisankan oleh masyarakat pemiliknya, seperti yang terdapat pada masyarakat Dawan di Kabupaten Timor Tengah Selatan. Sastra lisan masyarakat Dawan berbentuk prosa, puisi, dan nyanyian yang bersifat naratif dan puitis. Salah satu karya sastra lisan masyarakat Dawan berupa tonis. Tonis pada umumnya disejajarkan dengan tuturan yang berisikan doa kepada Yang Maha Kuasa, alam, dan leluhur, yang dikaitkan dengan bentuk upacara adatnya. Tonis pada masyarakat Dawan di Kabupaten Timor Tengah Selatan berciri puitis, metaforis, dan umumnya bersifat naratif. Istilah "tonis" (bahasa Dawan) secara harafiah berarti tuturan, dan "Natoni" berarti kegiatan menuturkan, sedangkan orang yang menuturkan disebut "Atonis". Khusus masyarakat Dawan di Kabupaten Timor Tengah Selatan, sastra lisan Dawan (tonis) berbentuk puisi naratif masih digunakan di setiap upacara adat baik yang berhubungan dengan pemerintah, pendidikan, agama, pertanian, maupun masyarakat khususnya.

Dikutip dari Liubana (2020: 58) Tonis dituturkan secara tradisional oleh orang yang dipercayakan untuk menuturkan. Penutur adalah pemimpin adat (Atonis/mafefa) 
Jurnal Onoma: Pendidikan, Bahasa dan Sastra PBSI FKIP Universitas Cokroaminoto Palopo Volume 6 Nomor 2
ISSN 2443-3667 (print)

ISSN 2715-4564 (online)

yang dalam struktur organisasi sosial selalu berperan sebagai penghubung antara dunia manusia dan dunia leluhur; antara rakyat biasa dengan para penguasa (usif); antara dunia manusia dengan Tuhan. Jenis sastra lisan tonis ini mengandung nilai-nilai budaya yang amat kaya, karena tonis dapat dituturkan pada berbagai kesempatan dan kepentingan ritual formal. Proses pelaksanaan dan tata cara yang berkaitan dengan penuturannya berbeda-beda, sesuai dengan fungsi dan tujuan penuturannya. Masyarakat Dawan memiliki kepercayaan bahwa tonis yang dilakukan secara benar akan mendatangkan kekuatan supranatural yang bersumber dari para leluhur, kekuatan alam, dan Ilahi, karena tonis yang dilakukan bersifat sakral. Pelaksanaan tonis biasanya dalam bentuk kelompok, seorang menjadi pemimpin yang bertugas menuturkan dari awal sampai akhir sedangkan anggotanya bertugas menuturkan kata terakhir dalam tiap baris kalimat secara serentak. Pelantunan tonis dilakukan secara bersahut-sahutan, dengan irama dan intonasi suara yang khas untuk menunjukkan makna dan keindahannya.

Berdasarkan hal itu penulis tertarik untuk melakukan penelitian yang dititikberatkan pada unsur pembentuk tuturan lisan tonis dari segi gaya bahasa. Sehubungan dengan tonis yang menjadi pokok pembahasan, dibatasi pada tonis dalam kegiatan perpisahan antara siswa yang telah lulus dengan pihak sekolah (SD) sebagai almamaternya. Dalam kegiatan tersebut, pihak sekolah mendatangkan tua adat (atonis) untuk menuturkan tuturan adat perpisahan sebagai suatu budaya yang selalu dilakukan ketika berlangsungnya pengumuman kelulusan siswa kelas VI SD yang telah mengikuti ujian akhir (Ujian Nasional). Bahasa yang dituturkan/disyairkan oleh atonis sangatlah unik dan indah karena menyiratkan makna dan nilai-nilai puitis di dalamnya, sehingga setiap orang yang mendengarnya dapat merasakan dan menginterpretasikan sendiri. Dalam tonis tersebut juga tersirat doa dan harapan selain ucapan syukur dan terima kasih kepada Tuhan, pihak sekolah dalam hal ini kepala sekolah, dewan guru, dan siswa kelas I sampai siswa kelas V (Liubana: 2020: 59).

Penulis menggunakan teori struktural sebagai acuan dalam penganalisisan tonis. Analisis sruktural pada prinsipnya bertujuan untuk membongkar dan memaparkan secara cermat, seteliti, semendetail, dan semendalam mungkin keterkaitan dan keterjalinan semua unsur dan aspek yang terkandung yang bersama-sama menghasilkan makna yang menyeluruh, Teeuw (Taum 2011: 283). Karya sastra mempunyai sebuah sistem yang terdiri atas seperangkat unsur yang saling berhubungan. Maka untuk mengetahui kaitan antarunsur dalam sebuah karya sastra itu penelaah teks sastra mengawali dengan pendekatan struktural. Pendekatan srtuktural memusatkan perhatian pada karya sastra itu sendiri, sebagai suatu dunia yang otonom. Sastra sebagai suatu totalitas mengandung suatu struktur yang hanya dapat dipahami berdasarkan unsur-unsurnya. Demikian juga unsurunsur tersebut memainkan peranan yang hakiki. Oleh sebab itu struktur karya sastra merupakan hubungan antara unsur-unsur pembentuk dalam suatu keseluruhan.

Sebagai konsekuensi praktisnya, analisis struktural terhadap karya sastra dilakukan dengan memusatkan perhatian hanya pada karyanya, mengungkapkan unsur-unsur pembangun strukturnya, dengan mengamati bentuk pertalian antarunsur yang membangunnya menjadi suatu struktur yang utuh, bulat, dan menyeluruh. Puisi adalah struktur yang merupakan susunan keseluruhan yang utuh antara bagian-bagian yang saling berhubungan. Tiap unsur dengan situasi tertentu tidak mempunyai arti dengan 
Jurnal Onoma: Pendidikan, Bahasa dan Sastra PBSI FKIP Universitas Cokroaminoto Palopo Volume 6 Nomor 2
ISSN 2443-3667 (print)

ISSN 2715-4564 (online)

sendirinya, melainkan ditentukan oleh hubungan dengan unsur-unsur lain yang terlibat dalam situasi itu. Salah satu unsur pembangun sebuah karya sastra adalah gaya bahasa.

Gaya bahasa merupakan cara pengarang mengungkapkan pikiran melalui bahasa secara khas yang memperlihatkan jiwa dan kepribadian penulis atau pemakai bahasa (Keraf, 2010:113). Demikian pula Tarigan (Ardin dkk, 2020:53) mengemukakan bahwa gaya bahasa adalah penggunaan kata-kata dalam berbicara dan menulis untuk meyakinkan atau memengaruhi penyimak dan pembaca. Pada dasarnya gaya bahasa digunakan dengan tujuan untuk menimbulkan kesan tertentu kepada penyimak atau pembaca. Gaya bahasa merupakan retorika, yakni menggunakan kata-kata dalam berbicara dan menulis untuk mempengaruhi pembaca dan pendengar (Al-Ma"ruf, 2009:15). Jadi gaya bahasa berfungsi sebagai alat untuk menyakinkan atau mempengaruhi pembaca dan pendengar. Sedangkan Ratna (2014:67) menyatakan tujuan utama gaya bahasa adalah menghadirkan aspek keindahan. Keindahan dalam bahasa sastra merupakan aspek urgen dalam karya sastra. Gaya bahasa ditentukan pula syarat-syarat dalam pemilihannya untuk dituangkan ke dalam karya sastra.

Gaya bahasa terdiri atas beberapa jenis, salah satunya gaya bahasa figuratif atau yang disebut figurative language. Bahasa figuratif sudah dikenal dan telah dipergunakan oleh novelis Romawi Cicero dan Suwetonius dengan istilah figura yang diartikan sebagai bayangan, gambar, sindiran, kiasan (Tarigan, 2013:5). Secara leksikal bahasa figuratif dapat diartikan sebagai bahasa yang bersifat kiasan atau bahasa yang bersifat lambang. Bahasa figuratif adalah bahasa yang melambangkan cara khas dalam menyatakan pikiran dan perasaan dalam bentuk pikiran atau lisan (Yakob, 2018:26).

Abrams (2010:96) mengatakan bahwa bahasa figuratif adalah bagian dari gaya bahasa yang berbentuk retorika. Retorika terbagi atas bahasa figuratif (figurative language) dan pencitraan (imagery). Bahasa figurative dibedakan menjadi dua, yaitu: (1) figure of thought atau thropes, yaitu penggunaan unsur kebiasaan yang menyimpang dari makna yang harafiah (literal meaning) atau pengungkapan dengan cara kias-sebut saja pemajasan; dan (2) figure of speech, rhetorical figures, atau schemes, yaitu menunjuk pada masalah pengurutan kata, masalah permainan struktur-sebut saja penyia-satan struktur.

Jenis gaya bahasa figuratif menurut Keraf (2002: 136-145), terdiri atas simile yaitu perbandingan yang bersifat eksplisit, yang ditandai dengan menggunakan kata pembanding yakni kata seperti, bagai, sama, sebagai, bagaikan, laksana, dan sebagainya; metafofa, sebagai analogi yang membandingkan dua hal secara langsung tetapi dalam bentuk yang singkat; Alegori, sebagi cerita singkat yang mengandung kiasan; Personifikasi, sebagai pembanding antara benda-benda mati yang disamakan dengan manusia; alusi, sebagai acuan yang berusaha mensugestikan kesamaan antara orang, tempat, peristiwa; eponim, menghubungkan nama seseorang dengan sifat tertentu; Epitet, menyatakan sifat atau ciri yang khusus dari seseorang; Sinekdoke, penggunaan sebagian sesuatu hal yang menyatakan keseluruhan; metonimia, menggunakan sebuah kata untuk menyatakan hal lain karena memiliki pertalian; Antonomasia, bentuk khusus dari sinekdoke untuk menggantikan nama diri, gelar resmi, dan atau jabatan; Hipalase, sebuah kata tertentu dgunakan untuk menerangkan kata yang seharusnya dikenakan pada kata lain; Ironi, sebagi gaya yang berisikan sindiran untuk menyatakan sesuatu hal yang berlainan dengan hal yang sesungguhnya; Satire, ungkapan yang menertawakan atau menolak sesuatu yang mengandung kritik tentang kelemahan manusia.

Halaman | 569 
Jurnal Onoma: Pendidikan, Bahasa dan Sastra PBSI FKIP Universitas Cokroaminoto Palopo Volume 6 Nomor 2
ISSN 2443-3667 (print)

ISSN 2715-4564 (online)

Selanjutnya menurut Perrine yang dikutip Waluyo, (1987: 83) bahasa figuratif dipandang lebih efektif untuk menyatakan apa yang dimaksud penyair, karena : 1) bahasa figuratif mampu menghasilkan kesenangan imajinatif; 2) bahasa figuratif adalah cara untuk menghasilkan imaji tambahan dalam puisi, sehingga yang abstrak menjadi konkret dan menjadi puisi yang nikmat untuk dibaca; 3) bahasa figuratif adalah cara menambah intensitas perasaan penyair untuk puisinya dan menyampaikan sikap penyair; 4) bahasa figuratif adalah cara untuk mengkonsentrasikan makna yang hendak disampaikan dan cara menyampaikan sesuatu yang banyak dan luas dengan bahasa yang singkat.

\section{Metode}

Penelitian ini termasuk jenis penelitian kualitatif. Hal ini sesuai dengan kajian yang bersifat deskriptif berupa data tulis atau data lisan dari orang atau perilaku yang diamati, khususnya terhadap tuturan lisan tonis. Paparan data, cara penjelasan data, maupun pemahaman tuturan lisan tonis pada masyarakat Dawan di Kabupaten Timor Tengah Selatan, Nusa Tenggara Timur dilakukan secara deskriptif. Sumber data berasal dari informan yang biasa menuturkan tonis dalam berbagai upacara adat. Informan yang dimaksud yaitu Tetua Adat yang dalam struktur organisasi sosial sebagai orang yang memiliki kemampuan atau dipercayakan untuk menuturkan tuturan lisan tonis atauyang disebut Atonis pada masyarakat Dawan tersebut. Penentuan informan berdasarkan beberapa kriteria yang berhubungan dengan nama, usia, agama, pekerjaan, tingkat pendidikan, bahasa sehari-hari yang digunakan, dan kedudukannya dalam masyarakat.

Pengumpulan data merujuk pada pendekatan yang dikemukakan oleh Sudikan (2011:173) bahwa pengumpulan data pada sastra lisan, menggunakan: observasi; perekaman; wawancara; dan pencatatan. Pengamatan adalah melihat dan mengamati suatu kejadian (tari, permainan, tingkah laku, nyanyian, tuturan dan lain-lain) dari gejala luarnya sampai ke dalamnya dan menggambarkan atau mendeskripsikan secara tepat hasil pengamatannya, (Taum, 2011: 239). Penelitian ini dilakukan dengan pengamatan secara langsung terhadap keberlangsungan kegiatan (natoni) atau kegiatan tuturan "tonis", sehingga dapat melihat dan mencatat sendiri urutan kegiatan tersebut. Selain itu digunakan keterampilan menggunakan alat perekaman (kamera atau video). Hal itu dimaksud untuk merekam tuturan yang dituturkan oleh tua adat (Atonis) pada saat kegiatan (natoni) perpisahan itu berlangsung.

Jenis data yang digunakan adalah data emik dan data etik. Data emik merupakan data utama. Data emik dalam penelitian ini berasal dari informan yakni, tuturan adat tonis perpisahan pada masyarakat Dawan. Data etik dalam penelitian ini adalah pengalaman, wawasan/pengetahuan dari penulis mengenai kajian struktur sebagai bahan dalam menganalisis data. Proses penganalisisisan data dilakukan dengan beberapa tahap yakni; pertama transkripsi dengan cara pengalihan dari bentuk lisan ke bentuk tulisan. Kedua, dalam studi sastra lisan sedapat mungkin diusahakan terjemahan kata demi kata (harafiah). Namun dengan demikian terjemahan tidak selalu secara harafiah saja tetapi terjemahan bebas atau dapat pula mencari padanan kata yang sesuai dengan makna katakata aslinya jika terjemahan harafiah menjadi tidak padu atau tidak sesuai dengan kaidahkaidah gramatikal bahasa Indonesia. Untuk itu penulis cenderung menggunakan terjemahan bebas. 
Jurnal Onoma: Pendidikan, Bahasa dan Sastra PBSI FKIP Universitas Cokroaminoto Palopo Volume 6 Nomor 2
ISSN 2443-3667 (print)

ISSN 2715-4564 (online)

Struktur bahasa figuratif sastra lisan tonis dianalisis dengan cara; mengindentifikasi tuturan lisan tonis tersebut dari bahasa figuratif. Menganalisis dengan menginterpretasi bagian kata-kata, frase yang menunjukan adanya gaya bahasa figuratif dan kiasan yang mengandung makna. Selanjutnya hasil interpretasi tersebut dideskripsikan secara mendetail, hingga mendapatkan simpulan yang akurat.

\section{Hasil dan Pembahasan}

\section{Hasil Terjemahan Tonis Secara Bebas}

Penutur I

Tonis Perpisahan

1. Lasi nak ona yo, bai uiskenum hai tua kenut hai am kenum nee...

Penutur II Dengan penuh hormat ... untuk raja kami yang dipertuan dan ...

2. Mok hai feto' hai nao'at hai oil enum hai muin menu alakim nee... Bersama saudara-saudari adik kakak ...

Haienkenu.

Ratu kami

Laliki.

Kami semua

3. Kan tokoman ta'at taeuk bokfa lek-lekom ta tolbokfa nee...

Lek-leok. Pertemuan ini bukan sekedar pertemuan ...

Biasa

4. Bihiti' eukam hiti' tokat hiti' nunkam nee ...

Buak Namun perjumpaan dan pertemuan ...

Kita semua

5. Mes noka'neu on hit etu noina tupa' noina intabut namtisin namno'ot inleuk nat namtisin nae...

Nam not.

Tapi dengan semua pelajaran yang waktunya telah genap dan selesai juga waktunya telah tiba dan ....

Genap

6. On in sufan in nesan in afan bi ton mes em eti ne ...

Mese'.

Yang diibaratkan seperti bunga telah berbuah dalam setahun dan... satu

7. Hai am enu on apanat apaot anoina' afenekat milenan misoman mihanan nee... Misom Bapak, ibu kami sebagai pelindung, penjaga, pengajar, penasehat, tak pernah bosan tak pernah ...

lelah

8. Bi ton ne in nanan eti ne nee ...

In nanan. Dalam setahun ...

Setiap waktu

9. Afi hai emat haim fain onle' fatu amonot ai' hau nee .... Amonot. Ketika kami datang, kami bagaikan batu yang tak mengerti, seperti kayu ... bodoh

10. Mesam tunomnane mam naetomnane on in usi' anesit afinit onan lek iman lulki on ate' un abaina' neu fatu amonot hau nee...

Amnonot. Tetapi semua yang dipertuan yang diutus untuk mengubah batu yang tak mengerti dan ... Kayu yang bodoh

11. Es on mite 'un mankaim mibana' mankai hai puni' ma'na'ka nee... Serta mengantar kami, mengubah kami orang perorang ...

12. Fain ona hietu hitupa' in nesan ai hipo'an hilene nee... Ibarat kebun dan ladang yang ...

Innesan. Berhasil

13. Meski nak bien simem lumnan mes on alail kaim on naka' mahenu' loen nee... Mahenu. Walaupun yang lain seperti sekam kosong tetapi kami semua berkepala penuh, berotak ...

14. Mes hian heun kai hem li'omam fanimam tipuomam fain ai' hemi ait' iomam mi'letnom neu etu SMP, yama' tupa' nee ...

SMP

Halaman | 571 
Jurnal Onoma: Pendidikan, Bahasa dan Sastra PBSI FKIP Universitas Cokroaminoto Palopo Volume 6 Nomor 2
ISSN 2443-3667 (print)

ISSN 2715-4564 (online)

Dan kami anak-anak mau berbalik, mau kembali atau mau melanjutkan ke ladang SMP dan tingkat ...

15. Masam tunom nane mam neyom nane fai ona hai ena' hai ama' ahointam atauwensat hai usim hai tuam ahointam nee ... Atauwenas. Tapi yang dipertuan sebagai ibu dan bapak kandung, sebagai penasihat sebagai pengajar yang kami pertuan sebagai ...

Guru

16. Maut hemi tumankaim mitiu' mankaitam poh'mankaimam na' mankai hemit nana'kaim mi'keisi' kai neu etu SMP in uis kenum intua kenut inam kenum nee ... Ankenu. Biarlah topang kami, sambungkan kami, hubungkan kami di pelantaran SMP yang dipertuan mereka bapak ...

$\mathrm{Ibu}$

17. Oin hemi' lil' lil' im mi' sak'sak' ut mesam nukamamsekat tam nukam nee ... Ma'mui'. Karena terburu-buru, gegabah akan tersesat dan ... Miskin

18. Bile' iyamsat hi anheunkai fain ona anuk tam ama'mui' tat a oel tam nee ... Alima at. Di sini juga kami anak-anakmu seperti yang termiskin dan kami lemah, tersesat dan...

Lemah

19. Hai luman kaim sona' kaim kam seun banin mibei'fa manekam alekot matakumnee... Alekot.

Kami kosong dan tak empunya untuk membalas kasihmu yang baik dan tuntunanmu yang....

20. Bito ne'in nanan eti nee ...

Baik Dalam setiap tahun dan dalam ...

21. Ai hai mitul um mina'ta neu ama' Uis Neno apinat aklahat amelat nee ... Hanya kami berserah kepada Tuhan Yang Pengasih dan ...

In nanan.

Setiap waktu

A'aekat.

Penyanyang

22. In mes esan soi' nabei' man ai nabei' hi hae hisuse hitni' nam nee ... Hanya Dialah yang menghitung, membalas jerih payah dan ...

Him opan. Jerih lelah

23. Nalalit hi han heun kai hai lima'e hai sanat hai penu le'napapa' hinekman nanu' eb nee Hinekam. Dan memenuhi kelemahan dan kekurangan serta kesalahan yang melukai... Hati 24. Nai ama 'Uis Neno esanatin palolim nalekot naloitnam nee .... Tuhan Allah yang akan memperbaiki dan memperbaharui ... Silakan

25. Hian heun kai alah haim mu'iyah hanaf senane saok' sanat neu hai santam hai penut tansium lum lumah hi manekmam nee ... Matakum. Anak-anakmu hanyalah memohon pengampunan untuk segala dosa dan salah untuk menerima ...

Restu

26. Es ahaket nanem am ninet nee ...

Nane Untuk itu kami ...

Bertutur

27. On mausi'kaim matua'kaim ma'ama'kaim nee ... Untuk kami bertuan dan berraja dan ... Ma ena'kai Beribu

28. Neu hai uiskenum hai tuakenut hai am kenum nee ... Haienkenu Untuk tuan kami, raja kami, bapak kami ... Ibu kami 29. Mok hai oil menum hai muin menut hai feot enum nee ... Beserta adik-adik kami ...

30. Henekam nenom ansaom neon nehiniaooo mana'pinat man nee ... Dari lubuk hati yang paling dalamyang dipertuan ... Hai nao'enu Muda-mudi kami Aklahat Yang diraja 
Jurnal Onoma: Pendidikan, Bahasa dan Sastra PBSI FKIP Universitas Cokroaminoto Palopo Volume 6 Nomor 2
ISSN 2443-3667 (print)

ISSN 2715-4564 (online)

\section{Bahasa Figuratif dalam Tonis}

Figurative language (bahasa figuratif) dalam tonis perpisahan pada masyarakat Dawan di Timor Tengah Selatan dimaksud, teridentifikasi beberapa jenis bahasa figuratif yaitu perbandingan, epos, personifikasi. Bahasa figuratif simile perbandingan terdapat pada data nomor; $9,12,13,15,18$; bahasa figuratif berjenis personifikasi tertera pada data $6,9,10,12,13$. Berikut pembahasan dari setiap bahasa figurtaif tersebut:

a. Simile

Perbandingan menunjukkan adanya dua sisi atau lebih yang dijelaskan dengan menggunakan kata pembanding (seperti, bagai, bagaikan, sebagai, umpama, ibarat, bak, laksana, se, sepantun, penaka, semisal, dan kata-kata pembanding lainnya. Seperti yang tertuang pada data berikut.

Afi hai emat haim fain onle' fatu amonot ai' hau nee ....

Amonot.

Ketika kami datang, kami bagaikan batu yang tak mengerti, seperti kayu ... Bodoh. (data, 9)

Pada data tersebut teridentifikasi bahasa figuratif perbandingan dengan penggunaan kata pembanding bagaikan (onle'). Kata bagaikan (onle') sebagai pembanding antara kalimat pertama 'ketika kami datang, kami' dan kalimat kedua 'batu yang tak mengerti', dan kata seperti merupakan pembanding antara kalimat kedua 'kami bagaikan batu yang tak mengerti' dan kalimat ketiga seperti kayu ... bodoh.' Kata bagaikan dan kata seperti menyatakan perbandingan dua hal yang berbeda. Pada kalimat tersebut penutur menunjukkan maksud bahwa siswa-siswa yang awalnya datang untuk belajar di sekolah tersebut (SD) masih polos, belum tahu baca dan tulis. Kata kami yang dimaksud adalah siswa-siswa diibaratkan seperti batu dan kayu. Dengan demikian maka, kata pembanding bagaikan dan seperti memberi makna pada kata batu dan kayu yaitu manusia diibaratkan sebagai benda mati.

Fain ona hietu hitupa' in nesan ai hipo'an hilene nee...

Innesan.

Ibarat kebun dan ladang yang ...

Berhasil (data, 12)

Pada data 12, terdapat bahasa figuratif perbandingan yang ditandai dengan kata ibarat. Namun kata ibarat yang dimaksud sebagai pembanding antara kalimat pada data 11 dengan data 12. Pada data 12 merupakan jawaban sambungan dari kalimat pada data 11 dengan bunyi kalimat 'Serta mengantar kami, mengubah kami orang perorang ...'. Selanjutnya kalimat 'ibarat kebun dan ladang yang ... berhasil' dapat memberi makna bahwa keberhasilan siswa-siswa (kami, orang-orang) diibaratkan sebagai kebun dan ladang yang memiliki hasil berupa kelulusan. Kata ibarat sebagai kata pembanding (persamaan) antara manusia dengan kebun atau ladang. Meski nak bien simem lumnan mes on alail kaim on naka' mahenu' loen nee... Mahenu. Walaupun yang lain seperti sekam kosong tetapi kami semua berkepala penuh, berotak ... penuh (data, 13)

Pada data 13 tersebut menunjukkan adanya bahasa figuratif perbandingan yang ditandai dengan kata seperti. Kata seperti dalam kalimat tersebut mengartikan persamaan antara 'yang lain' (orang lain) dengan 'sekam kosong'. Jika diartikan, sekam kosong adalah sejenis butiran padi yang tidak berisi. Sekam kosong dalam kalimat yang dituturkan oleh penutur (natoni) dapat ditafsirkan sebagai otak kosong, atau tak berilmu. Dalam penggalan tuturan tersebut, penutur mengibaratkan orang lain yang tidak sekolah seperti sekam kosong atau tidak berilmu. Sedangkan orang yang sekolah seperti ladang yang berhasil. Hal itu dapat dilihat pada pembahasan data 12 sebelumnya.

Halaman | 573 
Jurnal Onoma: Pendidikan, Bahasa dan Sastra PBSI FKIP Universitas Cokroaminoto Palopo Volume 6 Nomor 2
ISSN 2443-3667 (print)

ISSN 2715-4564 (online)

Masam tunom nane mam neyom nane fai ona hai ena' hai ama' ahointam atauwensat hai usim hai tuam ahointam nee... Atauwenas. Tapi yang dipertuan sebagai ibu dan bapak kandung, sebagai penasihat sebagai pengajar yang kami pertuan sebagai ...

Guru (Data, 15)

Kata sebagai merupakan tanda dari bahasa figuratif perbandingan yang tercantum dalam penggalan tuturan tersebut (data 15). Kata sebagai dalam kalimat tersebut menjelaskan persamaan ungkapan 'yang dipertuan' dengan ibu dan bapak kandung. Demikian pula dengan kalimat kedua, kata sebagai menjelaskan persamaan 'yang dipertuan' sebagai penasihat dan sebagai pengajar atau guru. Ungkapan yang dipertuan digunakan penutur dalam tonis tersebut dengan tujuan perumpamaan yang lebih halus ungkapannya daripada kata guru. Sama halnya dengan pengganti ungkapan kata ibu dan bapak kandung, .

Bile' iyamsat hi anheunkai fain ona anuk tam ama'mui' tat a oel tam nee ... Alima at. Di sini juga kami anak-anakmu seperti yang termiskin dan kami lemah, tersesat dan...

Lemah (data, 18)

Pada data 18 di atas menunjukkan adanya bahasa figuratif perbandingan yang diidentifikasikan dengan kata seperti. Kata seperti membandingkan (menyamakan) 'di sini kami anak-anakmu' dengan 'yang termiskin, dan kami lemah, tersesat dan lemah'. Maksud dari perbandingan tersebut adalah untuk menyatakan bahwa 'kami anak-anakmu diibaratkan orang yang miskin ilmu, lemah, tersesat, ketika masuk ke sekolah. Tetapi setelah mengenyam pendidikan dan memperoleh kelulusan 'kami menjadi kuat, kaya ilmu, mengerti akan pendidikan.

b. Personifikasi

Personifikasi sebagai salah satu bahasa figuratif tentang sifat kemunusiaan yang muncul pada benda-benda tak bernyawa, atau benda-benda mati seolah-olah memiliki nyawa dan bergerak seperti manusia. Pada data tuturan tonis perpisahan yang dikaji ini, teridentifikasi beberapa data yang memuat bahasa figuratif personifikasi. Data tersebut di antaranya: data nomor 6, 9, 10,12, dan 13 . Berikut pembahasan data-data tersebut. On in sufan in nesan in afan bi ton mes em eti ne... Mese'. Yang diibaratkan seperti bunga telah berbuah dalam setahun dan... Satu (data, 6)

Pada data nomor 6, kata bunga yang telah berbuah, mengibaratkan manusia. Bunga dilambangkan seperti manusia yang memiliki nyawa. Bunga yang telah berbuah menunjukkan bahwa siswa yang masuk ke sekolah tersebut dan belajar hingga lulus diibaratkan seperti bunga yang telah berbuah. Lebih spesifik lagi kata bunga menggambarkan siswa. Bunga diibaratkan sebagai siswa dalam hal ini manusia yang bergerak karena memiliki nyawa. Sama halnya dengan kutipan data nomor 9 dan 10.

Afi hai emat haim fain onle' fatu amonot ai' hau nee ... Amonot. Ketika kami datang, kami bagaikan batu yang tak mengerti, seperti kayu ...Bodoh (data, 9). Mesam tunomnane mam naetomnane on in usi' anesit afinit onan lek iman lulki on ate' un abaina' neu fatu amonot hau nee... Amnonot. Tetapi semua yang dipertuan yang diutus untuk mengubah batu yang tak mengerti dan ... Kayu yang bodoh (data, 10) 
Jurnal Onoma: Pendidikan, Bahasa dan Sastra PBSI FKIP Universitas Cokroaminoto Palopo Volume 6 Nomor 2
ISSN 2443-3667 (print)

ISSN 2715-4564 (online)

Pada data nomor 9 dan 10, menunjukkan adanya kata batu dan kayu yang melambangkan manusia. Kata batu dan kayu secara leksikal mengartikan benda mati, namun dalam kalimat tersebut menunujukkan adanya bahasa figurative personifikasi. Terlihat jelas pada kalimat tersebut, 'kami bagaikan batu yang tak mengerti, seperti kayu... bodoh'. Kata 'kami' yang dimaksud dalam kalimat itu, adalah siswa-siswa yang belajar di sekolah tersebut. Siswa-siswa dilambangkan sebagai ungkapan kata batu dan kayu yang dalam pengertiannya buta huruf, atau belum tahu membaca dan menulis, serta mengerti, ketika baru datang untuk belajar di sekolah tersebut. Pada data nomor 10, menjelaskan bahwa 'semua yang dipertuan' sebagai guru, diutus untuk mengubah batu dan kayu tersebut. Batu dan kayu dianggap memiliki nyawa seperti manusia. Siswa-siswa yang lulus diungkapkan oleh penutur bahwa sebelum mereka memperoleh kelulusan mereka seperti batu dan kayu yang perlu diajar agar pintar dan mengerti. Seperti halnya pada data nomor 12.

Fain ona hietu hitupa' in nesan ai hipo'an hilene nee...

Innesan.

Ibarat kebun dan ladang yang ...

Berhasil. (data, 12)

Pada kalimat data no 12, menunjukkan adanya bahasa figuratif personifikasi, yang ditekankan pada kata 'kebun' dan kata 'ladang'. Penutur mengungkapkan bahwa proses pembelajaran dari awal anak-anak mereka masuk sekolah hingga memperoleh kelulusan merupakan suatu hasil dari pembuatan kebun atau ladang. Keberhasilan anak-anak mereka berupa kelulusan dari sekolah tersebut diibaratkan sebagai hasil kebun atau ladang. Dengan demikian dapat disimpulkan bahwa kebun atau ladang termasuk proses perbuatan belajar dan mengajar dari unsur manusia (guru dan siswa) hingga meraih hasil.

Sedangkan pada data nomor 13, masih membicarakan tentang orang lain yang tidak bersekolah diibaratkan sebagai 'sekam kosong'. Terlihat pada kutipannya:

Meski nak bien simem lumnan mes on alail kaim on naka' mahenu' loen nee... Mahenu. Walaupun yang lain seperti sekam kosong tetapi kami semua berkepala penuh, berotak ... Penuh, (data, 13).

Ungkapan kalimat di atas, menunjukkan adanya personifikasi yakni frasa 'sekam kosong'. Penutur mengungkapkan bahwa 'yang lain' (orang lain) seperti 'sekam kosong' dalam pengertiannya orang lain yang tidak mengenal huruf, atau lebih jelasnya tidak mengerti atau pandai baca dan tulis, namun mereka yang bersekolah memiliki semua itu. Sekam kosong secara leksikal memberi pengertian bahwa kata sekam adalah bulir padi yang tak berisi (kosong). Orang yang tidak masuk dalam dunia pendidikan, terutama sekolah, adalah orang yang tidak memiliki kepandaian seperti orang yang sekolah.

Bahasa figuratif berupa personifikasi atau dalam pengertiannya yaitu benda-benda mati yang diibaratkan sebagai manusia, termuat dalam beberapa data dan ulasan di atas. Antara lain: pada data nomor 6 tentang 'bunga yang telah berbuah' (siswa-siswa yang berhasil lulus dalam proses belajar di sekolah); data nomor 9 dan 10, tentang 'batu dan kayu' yang melambangkan siswa-siswa yang awalnya masuk sekolah diibaratkan seperti itu; pada data ke 12 sekolah (proses belajar dan mengajar) yang dilakukan guru dan siswa diibaratkan sebagai 'kebun dan ladang'; dan yang terakhir tampak pada data nomor 13, yang mengungkapkan bahwa orang yang tidak mengenyam pendidikan dilambangkan sebagai 'sekam kosong'. 
Jurnal Onoma: Pendidikan, Bahasa dan Sastra PBSI FKIP Universitas Cokroaminoto Palopo Volume 6 Nomor 2
ISSN 2443-3667 (print)

ISSN 2715-4564 (online)

\section{Simpulan}

Hasil penelitian menunjukan adanya bahasa figuratif berjenis simile, dan personifikasi yang mendominasi tonis perpisahan tersebut. Temuan dalam kaitannya dengan struktur tonis dapat dijadikan sebagai sebuah kekayaan budaya lokal yang perlu diangkat di permukaan sehingga dikenal oleh seluruh masyarakat. Selain itu hasil kajian ini dapat dijadikan bahan apresiasi bagi kalangan pendidik, maupun pelajar di sekolah-sekolah, bahkan di Perguruan Tinggi. Terkait dengan ilmu sastra lisan, hasil kajian ini dapat berguna bagi peneliti-peneliti selanjutnya yang seyoganya akan meneliti penelitian serupa, sebagai bahan referensi tambahan.

\section{Daftar Pustaka}

Abrams, M. H. 2010. A Glosary In Literary Terms. New York: Holt.

Al-Ma'ruf, Ali Imron. 2009. Stilistika Teori, Metode dan Aplikasi Pengkajian Estetika Bahasa. Surakarta: Cakra Books

Ardin, Anita Safitri, dkk. 2020. Gaya Bahasa dalam Kumpulan Puisi Perahu Kertas Karya Sapardi Djoko Damono. Palu: Jurnal Bahasa dan Sastra Tadulako Vol. 5, Nomor 4.

Keraf, Goris. 2008. Diksi dan Gaya bahasa. Jakarta: Gramedia.

Liubana, Metropoly M. J. dan Ibrahim Nenohai. 2020. Struktur Bunyi dalam Tonis Perpisahan Pada Masyarakat Dawan di Kabupaten Timor Tengah Selatan. Kefamenanu: E-Jurnal Jubindo Vol. 5, Nomor 2.

Pradopo, R. D. 2012. Pengkajian Puisi. Yokyakarta: Gadja Mada University Press.

Ratna, Nyoman Kuta. 2009. Stilistika Kajian Puitika Bahasa, Sastra, dan Budaya. Yokyakarta: Pustaka Pelajar.

Ratna, Nyoman Kutha. 2014. Stilistika: Kajian Puitika, Sastra, dan Budaya. Yogyakarta: Pustaka Pelajar.

Sariban. 2009. Teori dan Penerapan Penelitian Sastra. Surabaya: Lentera Cendikia Surabaya.

Sudikan, Setya Yuwana. 2011. Metode Penelitian Sastra Lisan. Surabaya: Citra Wacana.

Taum, Yosep Yapi. 2011 Studi Sastra Lisan Sejarah, Teori, Metode, Pendekatan Disertai Contoh Penerapannya. Yokyakarta: Lamalera.

Tarigan, Henry Guntur. 2013. Pengajaran Gaya Bahasa. Bandung: Angkasa.

Waluyo, Herman J. 1987. Teori dan Apresiasi Puisi. Jakarta : Erlangga.

Yakob, Muhamad. 2018. Eksistensi Bahasa Figuratif dalam Cerita Pendek Sungai Karya Nugroho Notosusanto. Aceh: E-Jurnal Samudra Bahasa. Vol. 1, No. 1. 